\title{
DEVELOPMENTAL HISTORY OF CHARACTER EDUCATION AND HOW IT COULD BE DEFINED
}

\author{
Muhammad Ahkam Arifin \\ Institut Parahikma Indonesia (IPI), Gowa, Indonesia \\ e-mail: ahkam.arifin@gmail.com
}

\begin{abstract}
The central theme of this paper discusses the developmental history of character education (CE) and some definitions that have been referred to it. It first explores the historical development of character education that is mostly sourced in American history. Within this section, it is shown that character education seemed to decline between 1940s and 1960s, yet such other approaches to character education started emerging as 'values clarification' and 'moral dilemma discussion', although they both appeared to have different underlying theories. It then moves to some definitions of character education that have been put forward by different experts in the field; within the same title, the author of current paper also provides his own definition based on the mentioned facts.
\end{abstract}

Keywords: character education, moral education, values clarification, moral dilemma discussions, moral reasoning

\section{THE HISTORY OF CHARACTER EDUCATION}

\section{Early Character Education}

Dating back to the philosophers, Plato and Aristotle, of the two goals of education, that is, to help students become smart and good ${ }^{1}$, the notion of character education (CE), an approach to moral education, can be considered not new and "as old as education itself" ${ }^{2}$. The emergence of CE in formal education can be traced back to the colonial period in the $\mathrm{US}^{3}$, wherein schools provided explicit character training by instilling moral values largely based on the beliefs and ethics of Christianity ${ }^{4}$. However, between the 1940s and 1960s, it appeared to fall out of favour, due to the rapidly growing pluralism and secularisation in the American society ${ }^{5}$. Both rejected the idea of introducing religions into public education.

\footnotetext{
${ }^{1}$ Wren, T. Philosophical moorings. In L. Nucci, D. Narvaez, \& T. Krettanauer (Eds.), Handbook of moral and character education (2nd ed., pp. 11-29). (New York: Routledge, 2014)

${ }^{2}$ Lickona, T. The return of character education. Educational leadership, 51(3), 6-11. (1993)

${ }^{3}$ Mulkey, Y. J. The history of character education. Journal of Physical Education, Recreation \& Dance, 68(9), 35-37.(1997)

${ }^{4}$ Cunningham, C. A. A certain and reasoned art: The rise and fall of character education in America, In D. K. Lapsley \& F. C. Power (Eds.), Character psychology and character education, 166-200 (Notre Dame: University of Notre Dame Press, 2005)

${ }^{5}$ Lickona, Loc. Cit.
} 


\section{A Revival of Character Education after Its Decline}

\section{Values Clarification}

A revival of interest in CE was seen in the late 1960s, as a result of the movement of "values clarification", pioneered by Louis Rath ${ }^{6}$. Unlike the above early model of CE, values clarification considered teachers' job "to help students learn how to clarify their own values" and teachers did "not try to teach values at all,

Nevertheless, it also declined as a result of its failure to draw firm distinctions between moral values (a matter of obligation) and other values, or personal preferences (truly a matter of free choice) ${ }^{8}$. In other words, this approach was regarded as relativistic in the extreme ${ }^{9}$. Lockwood claims that, in this programme, there was no right or wrong; any values that students chose were considered right, as long as they could provide a rationale ${ }^{10}$. Another reason of its downturn was caused by the lack of empirical support of its positive impact ${ }^{11}$.

\section{Moral Dilemma Discussion}

The influence of values clarification appeared to be eclipsed by Kohleberg`s cognitive-developmental approach in the 1970s and early $1980 \mathrm{~s}^{12}$. This approach was also called moral reasoning, or moral dilemma discussion ${ }^{13}$. Growing from his research on discussing the hypothetical ethical dilemmas in curriculum ${ }^{14}$, Kohlberg attempted to nurture students based on the prescribed six stages of increasingly complex moral reasoning ${ }^{15}$ (see Appendix I for the stages). This model claimed to reject the relativism as proposed by values clarification ${ }^{16}$.

However, Lickona critiqued that this model was an improvement over values clarification, in that it still underestimated the role of the school as a moral socialiser. Students were encouraged to reason through situations, and teachers were merely facilitators of discussing moral dilemmas, but not teaching values, and judging the values chosen by students. In other words, like values clarification, the focus was

\footnotetext{
${ }^{6}$ Lickona. Educating for character: How our schools can teach respect and responsibility. (New York: N.Y: Bantam, 1991)

${ }^{7}$ Lickona, Op. Cit. (1991)

${ }^{8}$ Lickona, Op. Cit. (1993)

${ }^{9}$ Howard, R. W., Berkowitz, M. W., \& Schaeffer, E. F. (2004). Politics of character education. Educational policy, 18(1), 188-215. (2004)

${ }^{10}$ Lockwood. A Letter to Character Education. Educational Leadership, 51(3), 72-75. (1993)

${ }^{11}$ Berkowitz, M. W., \& Bier, M. C.What works in character education? Journal of Research in Character Education, 5(1), 29. (2002)

${ }^{12}$ Howard, R. W., Berkowitz, M. W., \& Schaeffer, E. F. Politics of character education. Educational policy, 18(1), 188-215. (2004)

${ }^{13}$ Narvaez, D., \& Bock, T. (2014). Developing ethical expertise and moral personalities. In L. Nucci \& D. Narvaez (Eds.), Handbook of Moral and Character Education (2nd Ed.) (pp. 140-158). (New York: Routledge, 2014)

${ }^{14}$ Howard, et al., Loc. Cit.

${ }^{15}$ Kohlberg, L. Stages of moral development. Moral education, 23-92. (1991)

${ }^{16}$ Lickona, T. Character Education: The Heart of School Reform. Religion \& Education, 27(1), 58-64. (2000)
} 
only on moral thinking rather than developing a full human character based on an objective standard of goodness.

\section{A New Character Education Movement}

According to Lickona ${ }^{17}$, the beginning of a new CE movement was observed in the 1990s. One of the triggers was the report by the National Research Council of the US in 1992 demonstrating the US to be the most violent among industrialised nations. This new model is said to be different from the previous two approaches (values clarification and moral dilemma discussion), in that both appear to reject the concept of universal moral values ${ }^{18}$. This new movement, as Lickona simply calls it "character education", by contrast, attempts to instil students with moral values, or virtues (e.g., wisdom, kindness, patience), which are considered "good human qualities that transcend time and culture" ${ }^{\prime 19}$.

This new approach appears, in many ways, to follow the earliest model of CE (2.1.1), which was based on religious beliefs. Lickona, the pioneer of this movement, posits that the vision of religious (Christian and Catholic) schools on CE should be based on the character of Christ, while secular schools should focus on universal moral values, yet without completely ignoring students` religious beliefs ${ }^{20}$. However, Lockwood asserts that this could become a serious weakness of this approach, in that it may face the same fate as the earliest model, which was also based on religious values, and, once again, may lead this model to failure ${ }^{21}$.

Additionally, Lockwood questions that this approach claims to reject the "ineffective" values clarification and Kohlberg's moral development, yet still wants students to reason things on their own, that is, to select the most ethical solution based on the solutions the student can think of. Lockwood explicitly states that "I find this most confusing" and asks "when is each situation appropriate?"22; the situation when teachers should tell students what values to choose or the situation when students should make their own decisions.

Despite the criticisms, this new CE model appears to be implemented, up to now, throughout public schools in America, as is evident in the Character Education Informational Handbook and Guide $I I^{23}$. This model is also currently applied in UK contexts, as indicated in the research report on Character Education in UK Schools ${ }^{24}$. Nevertheless, to date, the two previous models (values clarification and moral

\footnotetext{
${ }^{17}$ Lickona, op. cit. (1993)

${ }^{18}$ Lickona, op. cit (2000)

${ }^{19}$ Ibid, p. 60
}

${ }^{20}$ (Dimerman, 2009)Dimerman, S. Character is the Key: How to Unlock the Best in our Children and Ourselves. (Mississauga, Canada: John Wiley \& Sons, 2009)

${ }^{21}$ Lockwood, op. cit. (1993)

${ }^{22}$ Ibid, p. 74

${ }^{23}$ Character Education Informational Handbook and Guide II. Character Education Informational Handbook \& Guide II. (2006). Support and Implementation of the Student Citizen Act of 2001 (Character and Civic Education). Public Schools of North Carolina. Retrieved June 7, 2016 from http://www.dpi.state.nc.us/docs/charactereducation/handbook/content2.pdf(2006)

${ }^{24}$ Arthur, J., Kristjánsson, K., Walker, D., Sanderse, W., \& Jones, C. Character education in UK schools: Research report. (2015) 
dilemma discussion) still have influence ${ }^{25}$. (See Appendix IIA for an overview of the history of CE).

\section{THE DEFINITION OF CHARACTER EDUCATION}

One potential limitation of CE is the lack of a consistent standard definition ${ }^{26}$, which may influence the findings of research within the field. However, from the historical perspective ${ }^{27}$, contemporary definitions of $\mathrm{CE}$, apparently, can be distinguished into two broad divisions ${ }^{28}$ : (1) those who claim that the ultimate function of judgements is made in context, or that students should determine their own moral values (a values-neutral approach) and (2) those who argue that teachers should cultivate students with certain moral values (a virtues-based approach). Notwithstanding, both have a similar vision of "fundamentally fostering the optimal positive development of students ${ }^{\prime 29}$. This distinction will direct the two following sections.

\section{Values-Neutral Approach}

Character educators who fall within a values-based approach, also called a progressive/constructivist approach, are those who focus on the development of moral reasoning ${ }^{30}$. They emphasize the role of reason and judgment based upon a rationalist, philosophical perspective, with the emphasis "on autonomous justification for moral actions based on principles of justice or fairness" $"$.

Both values clarification and moral dilemma discussions have been considered to subscribe to this philosophical perspective, as both have a similar objective, that is, teachers are not to moralise ${ }^{32}$. Teachers merely facilitate the valuing process and, for fear of influencing students, withhold personal opinions, and they are to respect whatever values students arrive at (ibid). The difference in these two models is that values clarification recommends the seven-step valuing process (see Appendix III), whereas Kohlberg recommends six stages (see Appendix I).

\footnotetext{
${ }^{25}$ Lisievici, P., \&Andronie, M. Teachers Assessing the Effectiveness of Values Clarification Techniques in Moral Education. Procedia-Social and Behavioral Sciences, 217, 400-406. (2016)

${ }^{26}$ Lewis, S. V., Robinson III, E. H., \& Hays, B. G. Implementing an authentic character education curriculum. Childhood Education, 87(4), 227-231. (2011)

${ }^{27}$ Pattaro. Character Education: Themes and Researches. An Academic Literature Review. Italian Journal of Sociology of Education, 8(1). (2016)

${ }^{28}$ Nucci, L., Narvaez D., Krettanauer, T. Introduction and Overview. In L. Nucci, D. Narvaez, \& T. Krettanauer (Eds.), Handbook of moral and character education (2nd ed., pp. 11-29). (New York, NY: Routledge, 2014)

${ }^{29}$ Berkowitz, M. W., \& Bustamante, A. Using research to set priorities for character education in schools: A global perspective. KEDI Journal of Educational Policy, 10(3).(2013). P. 8

${ }^{30}$ Nucci, L. P. Education for moral development. In M. Killen \& J. G. Smetana (Eds.), Handbook of moral development (pp. 657-681). (New Jersey: Lawrence Erlbaum Associates, 2006)

${ }^{31}$ Nucci et al., loc. cit.(2014)

${ }^{32}$ Leming, J. S. In search of effective character education. Educational Leadership, 51(3), 6371. (1993)
} 
Current well-known researchers who seem to subscribe to this stance are Rest et al. $^{33}$. They call themselves Neo-Kohlbergian, as they, in many ways, "follow Kohlberg's approach to conceptualising moral judgement"34, yet differ in their approach on how to develop students moral reasoning. The Neo-Kohlbergian postulates three moral schemas (see Appendix IV). They use the term "schemas" rather than "stages" to distinguish their approach to that of Kohlberg. (Appendix IIB shows an overview of this values-neutral stance.)

However, this approach, that believes "what counts as a virtue varies as a function of a cultural and historical setting",35, has been critiqued by Lapsley ${ }^{36}$. Lapsley carried out research comparing the checklist of virtues from his own elementary school report card with the list of 23 virtues to be used as core values in several CE programs that had been compiled in 1988 and reported that there are, indeed, moral values that transcend cultural and historical setting. Laspley only found one that overlapped, that is, courtesy.

\section{Values-Based Approach}

This approach is in stark contrast to the neutrality of moral dilemma discussion and values clarification $^{37}$. It seeks to inculcate students with virtues, yet employs moral reasoning as one of the strategies ${ }^{38}$. A values-based approach, also called a traditional approach to $\mathrm{CE}^{39}$, in general, traces its concept back to Aristotle`s observation that moral virtues cannot be taught, but must be learnt by doing. The objective is to form individuals with a virtuous character as a habit through virtuous $\operatorname{action}^{40}$.

Character education by Lickonaand the early model of CE can be regarded as values-based approaches, in that both regard $\mathrm{CE}$ as "the deliberate effort to cultivate virtues" to students, wherein teachers, or schools, promote virtues explicitly ${ }^{41}$. The slight difference is that, while the former focuses on universally accepted moral values, the latter focuses on religious (Catholic and Christian) beliefs.

It is worth pointing out that the opposite group, values-neutral approaches, critique the idea of cultivating values to students, as, they claim, "subscribing to any

\footnotetext{
${ }^{33}$ Rest, J. R., Narvaez, D., Thoma, S. J., \&Bebeau, M. J. A neo-Kohlbergian approach to morality research. Journal of moral education, 29(4), 381-395. (2000)

${ }^{34}$ Ibid

${ }^{35}$ Pandey, V.C. Value Education and Education for Human Rights. (Delhi: Isha Books, 2005). P. 219

${ }^{36}$ Lapsley (1996) Lapsley, D. Moral psychology. (Boulder, CO: Westview., 1996)

${ }^{37}$ Nucci et al., op. cit (2014)

${ }^{38}$ Lockwood, A. L. A Letter to Character Education. Educational Leadership, 51(3), 72-75.

39 Arthur. Traditional approaches to character education in Britain and America. In L. P. Nucci \& D. Narvaez (Eds.), Handbook of moral and character education (pp. 80- 98). (New York, NY: Routledge, 2008)

${ }^{40}$ Chambliss, J. J. Philosophy of education today. Educational Theory, 59(2), 233-251. (2009)

${ }^{41}$ Lickona, T. Character education: Seven crucial issues. Action in Teacher Education, 20(4), 77-84. (1999). P. 78
} 
set of values is deeply problematic in a pluralistic society", which then leads them to focus more on "an implicit character education rationale without, subscribing to any particular set of values" ${ }^{42}$. In other words, their focus on moral education is not to instil values, yet to be critical in clarifying values that need to be selected based on the contexts. This distinction seems to be important, on reviewing relevant studies, as the focus of the two is different.

\section{The Definition of Character Education According to the Author}

The author of the current paper decides to subscribe to the definition of CE that is employed is the definition proposed by a virtues-based approach, that is, to promote moral values, or virtues, to students. The reason for this is because Berkowitz and Bier, in reviewing seventy-eight studies on character education, reveal that, regardless of the labels "character education, social-emotional learning, school-based prevention, citizenship education, etc" ${ }^{43}$, the main purpose remains the same, that is, to instruct students in moral values. Arthur also mentions that the terms, values education and moral education, aim for the same thing, that is, to promote moral virtues $^{44}$.

It should, however, be distinguished from values clarification and moral dilemma discussion (values-neutral approaches), which aim to not instil values. Thus, throughout this study, particularly in reviewing the relevant studies, the term character education (CE) is employed as an umbrella for all the aforementioned labels, other than values clarification and moral dilemma discussion, to refer to an approach to improve students` character, or morality, by promoting moral values.

\section{REFERENCES}

Arthur, J. (2005). The re-emergence of character education in British education policy. British Journal of Educational Studies, 53(3), 239-254.

Arthur, J. (2008). Traditional approaches to character education in Britain and America. In L. P. Nucci \& D. Narvaez (Eds.), Handbook of moral and character education (pp. 80-98). New York, NY: Routledge.

Arthur, J., Kristjánsson, K., Walker, D., Sanderse, W., \& Jones, C. (2015). Character education in UK schools: Research report.

Berkowitz, M. W., \& Bier, M. C. (2007). What works in character education? Journal of Research in Character Education, 5(1), 29.

Berkowitz, M. W., \& Bier, M. C. (2007). What works in character education? Journal of Research in Character Education, 5(1), 29.

\footnotetext{
${ }^{42}$ Arthur, op. cit. (2005) p. 249

${ }^{43}$ Berkowitz, M. W., \& Bier, M. C. What works in character education? Journal of Research in Character Education, 5(1), 29. (2007). P. 3

${ }^{44}$ Arthur, J. The re-emergence of character education in British education policy. British Journal of Educational Studies, 53(3), 239-254. (2005)
} 
Berkowitz, M. W., \& Bustamante, A. (2013). Using research to set priorities for character education in schools: A global perspective. KEDI Journal of Educational Policy, 10(3).

Chambliss, J. J. (2009). Philosophy of education today. Educational Theory, 59(2), 233-251.

Character Education Informational Handbook and Guide II (2006) Character Education Informational Handbook \& Guide II. (2006). Support and Implementation of the Student Citizen Act of 2001 (Character and Civic Education). Public Schools of North Carolina. Retrieved June 7, 2016 from http://www.dpi.state.nc.us/docs/charactereducation/handbook/content2.pdf

Character Education: The Heart of School Reform. Religion \& Education, 27(1), 5864.

Character is the Key: How to Unlock the Best in our Children and Ourselves. Mississauga, Canada: John Wiley \& Sons.

Cunningham, C. A. (2005), A certain and reasoned art: The rise and fall of character education in America, In D. K. Lapsley \& F. C. Power (Eds.), Character psychology and character education, 166-200, Notre Dame, IN: University of Notre Dame Press.

Howard, R. W., Berkowitz, M. W., \& Schaeffer, E. F. (2004). Politics of character education. Educational policy, 18(1), 188-215.

Howard, R. W., Berkowitz, M. W., \& Schaeffer, E. F. (2004). Politics of character education. Educational policy, 18(1), 188-215.

Kohlberg, L. (1971). Stages of moral development. Moral education, 23-92.

Lapsley, D. (1996). Moral psychology. Boulder, CO: Westview.

Leming, J. S. (1993). In search of effective character education. Educational Leadership, 51(3), 63-71.

Lewis, S. V., Robinson III, E. H., \& Hays, B. G. (2011). Implementing an authentic character education curriculum. Childhood Education, 87(4), 227-231.

Lickona, T. (1991) Educating for character: How our schools can teach respect and responsibility. New York, N.Y: Bantam

Lickona, T. (1993). The return of character education. Educational leadership, 51(3), 6-11.

Lickona, T. (1999a). Character education: Seven crucial issues. Action in Teacher Education, 20(4), 77-84.

Lisievici, P., \&Andronie, M. (2016). Teachers Assessing the Effectiveness of Values Clarification Techniques in Moral Education. Procedia-Social and Behavioral Sciences, 217, 400-406.

Lockwood, A. L. (1993). A Letter to Character Education. Educational Leadership, 51(3), 72-75.

Mulkey, Y. J. (1997). The history of character education. Journal of Physical Education, Recreation \& Dance, 68(9), 35-37.

Narvaez, D., \& Bock, T. (2014). Developing ethical expertise and moral personalities. In L. Nucci \& D. Narvaez (Eds.), Handbook of Moral and Character Education (2nd Ed.) (pp. 140-158). New York, NY: Routledge.

Nucci, L. P. (2006). Education for moral development. In M. Killen \& J. G. Smetana (Eds.), Handbook of moral development (pp. 657-681). New Jersey: Lawrence Erlbaum Associates. 
Nucci, L., Narvaez D., Krettanauer, T. (2014). Introduction and Overview. In L. Nucci, D. Narvaez, \& T. Krettanauer (Eds.), Handbook of moral and character education (2nd ed., pp. 11-29). New York, NY: Routledge.

Pandey, V.C. (2005). Value Education and Education for Human Rights. Delhi: Isha Books.

Pattaro, C. (2016). Character Education: Themes and Researches. An Academic Literature Review. Italian Journal of Sociology of Education, 8(1).

Rest, J. R., Narvaez, D., Thoma, S. J., \&Bebeau, M. J. (2000). A neo-Kohlbergian approach to morality research. Journal of moral education, 29(4), 381-395.

Wren, T. (2014). Philosophical moorings. In L. Nucci, D. Narvaez, \& T. Krettanauer (Eds.), Handbook of moral and character education (2nd ed., pp. 11-29). New York, NY: Routledge. 